Cystic fibrosis (CF) is caused by mutations in the CF gene, which encodes CF transmembrane conductance regulator protein (CFTR), a transmembrane protein that acts as a cAMP-regulated chloride channel. The disease is characterized by inflammation but the relationship between inflammation, abnormal transepithelial ion transport, and the clinical manifestations of CF are uncertain. The present study was undertaken to determine whether three nonsteroidal anti-inflammatory drugs (NSAIDs) (aspirin, ibuprofen, and indomethacin) modulate CFTR gene expression in T-84 cells. Treatment with NSAIDs reduced CFTR transcripts, and decreased cAMP-stimulated anion fluxes, an index of CFTR function. However, the two phenomena occurred at different concentrations of both drugs. The results indicate that NSAIDs can regulate both CFTR gene expression and the function of CFTR-related chloride transport, and suggest that NSAIDs act via multiple transduction pathways.

Keywords: CFTR, Gene expression, T-84 Cells, Aspirin, Nonsteroidal anti-inflammatory drugs

\section{Aspirin and some other nonsteroidal anti-inflammatory drugs inhibit cystic fibrosis transmembrane conductance regulator protein gene expression
in T-84 cells}

Danielle Tondelier ${ }^{1}$, Franck Brouillard' ${ }^{1}$, Joanna Lipecka ${ }^{1}$, Régis Labarthe ${ }^{1}$, Moëz Bali ${ }^{1}$, Marie-Ayliette Costa de Beauregard ${ }^{2}$, Tanja Torossi ${ }^{1}$, Marc Cougnon ${ }^{1}$, Aleksander Edelman ${ }^{1, C A}$ and Maryvonne Baudouin-Legros ${ }^{1}$

${ }^{1}$ INSERM U. 467, Faculté de Médecine Necker-Enfants Malades, 156 rue de Vaugirard, 75015 Paris; ${ }^{2}$ UMR 144, Institut Curie, 25 rue d'Ulm, 75005 Paris, France

\author{
${ }^{\mathrm{CA}}$ Corresponding Author \\ Tel: $(+33) 140615628$ \\ Fax: (+ 33) 140615591 \\ Email: edelman@necker.fr
}

\section{Introduction}

Inflammation in response to an external attack or internal malfunction triggers the synthesis of many extra- and intracellular mediators that can modulate the activity of the cell's membrane, cytoplasm and nucleus. The inhibitory effects of aspirin on most inflammatory responses have long been attributed to its ability to block the synthesis of prostaglandins. These natural autacoids produced by cyclooxygenase activation provoke inflammation. ${ }^{1}$ It is now well established that aspirin and the other nonsteroidal anti-inflammatory drugs (NSAIDs) also modulate membrane ${ }^{2-6}$ and nuclear ${ }^{7-9}$ responses independently of the inhibition of cyclooxygenase. This raises questions about the molecular reactions contributing to the beneficial effects of NSAIDs on the symptoms of cystic fibrosis (CF). ${ }^{10}$

$\mathrm{CF}$ transmembrane conductance regulator protein (CFTR) is known to act as a cAMP-activated anionic channel. Clinical manife stations of $\mathrm{CF}$ are correlated with mutations in the CF gene, which cause the protein it makes to function abnormally. ${ }^{11}$ However, $\mathrm{CF}$ involves not only hydroelectrolytic abnormalities, but also chronic inflammation and infection, and antiinflammatory therapies improve the clinical condition of patients. The link between changes in anionic transmembrane transport and inflammation is uncertain, and some observations suggest that NSAIDs may have a dual effect in $\mathrm{CF}$, combining inhibition of inflammation with the modulation of anion transmembrane trans port.

Several effects of rapid modulations in ionic conductances by NSAIDs have been described. For example, the fenamates (niflumic and flufenamic acids) block the nonselective ion channels in rat exocrine pancreas, ${ }^{3}$ or activate the voltage-dependent $\mathrm{K}$ current expressed in Xenopus oocytes. ${ }^{6}$ Several reports indicate that NSAIDs alter chloride conductances in epithelial cells. Short applications of NSAIDs inhibit $\mathrm{Ca}^{2+}$ - and cAMP-regulated chloride secretion of cultured tracheal epithelial cells. ${ }^{4}$ The fenamates also modulate chloride conductance in bovine retinal pigment epithelium, but in a more complex way. ${ }^{5}$ Recently, it was reported that ibuprofen blocks the CFTR-mediated chloride secretion in T-84 cells and in human and mouse tracheal epithelia. ${ }^{2}$ Other data suggest that aspirin and other NSAIDs 
might modulate CFTR gene expression by modulating various transcription factors which bind to specific nucleotidic sequences present in the CFTR promoter. ${ }^{12}$ Aspirin has been shown to inhibit the activation of transcription factors such as $\mathrm{NFKB}^{7}$ and $\mathrm{AP}_{1}{ }^{8}$, and to facilitate the binding capacity of the Heat

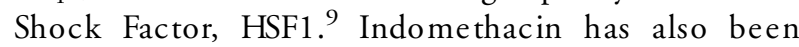
show $n$ to inhibit the activation of AP- $1 .{ }^{8}$ We suggested that aspirin may control CFTR gene expression. This would not be the first 'nuclear effect' of the drug, since aspirin had already been shown to suppress inflammation-induced expression of interleukin-1 (Il1), Il-6 and adhesion molecules in Hela cells ${ }^{7}$ and to inhibit the synthesis of IL-1-induced PGH synthase. ${ }^{13}$

The present study was undertaken to determine whether aspirin, ibuprofen, and indome thacin modify CFTR gene function. We did this by measuring CFTR transcripts and cAMP-stimulated anion fluxes, these being indices of CFTR function in T-84 cells.

\section{Materials and methods}

\section{Cell culture and drug treatment}

Human T-84 carcinoma cells were obtained from the American Type Culture Collection (Rockville, MD) and propagated in a mixture (1:1) of Dubelcco's modified Eagle's medium (DMEM) and Ham's F-12 medium containing $15 \mathrm{mM}$ Hepes and $10 \%$ fetal calf serum (FCS). LLCPK cells stably transfected with wild type CFTR, $\Delta \mathrm{F}_{508}-\mathrm{CFTR}$, and nontransfected cells were both cultured in DMEM medium.

The cells were seeded at a density of $2 \times 10^{4} / \mathrm{cm}^{2}$. Stock solutions of aspirin $(1 \mathrm{~mol} / \mathrm{l})$, indomethacin $\left(5 \times 10^{-3} \mathrm{~mol} / \mathrm{l}\right)$, and ibuprofen $\left(10^{-2} \mathrm{~mol} / \mathrm{l}\right)$ were made up in ethanol. On the third day after passage, the cells were treated with aspirin or the other NSAIDs in FCS-enriched medium. RNA was analyzed after $24 \mathrm{~h}$ of treatment (except for kinetic studies). Functional studies were performed on T-84 cells incubated with the drugs for $48 \mathrm{~h}$. Control cells received the same volume of solvent $(<1 \%)$. All the culture materials were obtained from Life Technologies (Les Ulis, France); the drugs were from Sigma (France).

\section{Analysis of cell viability}

In a preliminary series of experiments we verified that, even at the highest concentrations used in this study, the drugs were not toxic. Cells maintained under control conditions, or after a 48 h treatment with aspirin $\left(10^{-3} \mathrm{~mol} / \mathrm{l}\right)$, indome thacin $\left(2 \times 10^{-5} \mathrm{~mol} /\right.$ 1), or ibuprofen $\left(5 \times 10^{-4} \mathrm{~mol} / \mathrm{l}\right)$ were washed with phosphate-buffered saline (PBS), trypsinized, suspended in serum-free medium, and centrifuged. Cells were washed twice more with PBS and suspended in PBS. Parts of this suspension were used to test cell viability with trypan blue, for counting cells in a Malassez cell, and to measure protein concentration according to Low ry et al. ${ }^{14}$

Cell counting and trypan blue exclusion test showed that when $10^{-3} \mathrm{~mol} / \mathrm{l}$ aspirin was added to T-84 cells for a 48 h incubation, it neither killed them nor altered their proliferation rate. The same treatment also had no effect on the protein content of the culture. The same results were observed after $48 \mathrm{~h}$ incubation with $2 \times 10^{-5} \mathrm{~mol} / \mathrm{l}$ indomethacin and $5 \times 10^{-4} \mathrm{~mol} / \mathrm{l}$ ibuprofen (Table 1 ).

\section{RNA extraction and analysis}

Total RNA was isolated with phenol/chloroform ${ }^{15}$ using the Trizol reagent (Life Technologies), according to the manufacture r's instructions. The RNA was then fractionated on $0.9 \%$ agarose gels $(15 \mu \mathrm{g} / \mathrm{w}$ ell $)$, transferred to nylon membranes (Promega Charbonnières, France) and fixed by heating. The filters were hybridized to ${ }^{32} \mathrm{P}$-labeled cDNA probes (specific activity $>10^{9} \mathrm{cpm} / \mathrm{mg}$ ) with the Quik Hyb protocol provided by Stratage ne (Ozyme, Les Ulis, France), washed under stringent conditions (0.1 SSC, $0.1 \%$ sodium docdecyl sulfate at $52^{\circ} \mathrm{C}$ for $20 \mathrm{~min}$ ) and autoradiographed at $-80^{\circ} \mathrm{C}$. The CFTR probe was the $1.5 \mathrm{~kb} E c o \mathrm{R} 1-E c o \mathrm{R} 1$ fragment of human CFTR-cDNA probe labeled by random priming. The membranes were rehybridized with a human $\beta$-actin cDNA probe from Oncogene Science (France Biochem, Meudon, France). The mRNAs were quantifie $\mathrm{d}$ by densitome tric scanning of the autoradiograms on an ImageMaster

Table 1. Effects on NSAIDs on cell proliferation

\begin{tabular}{lccc}
\hline & $\begin{array}{c}\text { Number of cells } \\
\left(10^{6} \text { cells/well }\right)\end{array}$ & $\begin{array}{l}\text { Living cells } \\
(\% \text { of total })\end{array}$ & $\begin{array}{c}\text { Cell protein } \\
(\mu \mathrm{g} / \text { well })\end{array}$ \\
\hline Control & $1.55 \pm 0.11$ & $90.9 \pm 2.4$ & $220 \pm 25$ \\
Aspirin $\left(5 \times 10^{-4} \mathrm{~mol} / \mathrm{l}\right)$ & $1.85 \pm 0.25$ & $91.3 \pm 2.7$ & $234 \pm 21$ \\
Aspirin $\left(10^{-3} \mathrm{~mol} / \mathrm{l}\right)$ & $1.40 \pm 0.06$ & $91.4 \pm 3$ & $223 \pm 30$ \\
Indomethacin $\left(2 \times 10^{-5} \mathrm{~mol} / \mathrm{l}\right)$ & $1.40 \pm 0.15$ & $89.2 \pm 2.9$ & $205 \pm 28$ \\
Ibuprofen $\left(5 \times 10^{-4} \mathrm{~mol} / \mathrm{l}\right)$ & $1.63 \pm 0.22$ & $90.5 \pm 2.6$ & $220 \pm 21$ \\
\hline
\end{tabular}

The number of cells per well, the percentage of living cells, and the protein content were determined as described in materials and methods on cultures maintained under control conditions or treated for $48 \mathrm{~h}$ with the various NSAIDs. Each value is the mean \pm SE of three determinations performed in triplicate on three different cultures. 
VSD (Pharmacia-Biotech-Amersham, Orsay, France), and CFTR mRNA amounts were normalized to those of $\beta$-actin. All experiments were repeated at least four times.

\section{6-Methoxy- $N$-ethylquinolinium fluorescence assay}

The 6-methoxy-N-ethylquinolinium (MEQ) w as synthesized in the laboratory according to the method described by Biwersi and Verkman. ${ }^{16}$ 6-Methoxyquinoline $(20 \mathrm{mmol})$ and iondoethane $(40 \mathrm{mmol})$ were allowed to react for $1 \mathrm{~h}$ with continuous stirring and boiling. After cooling, the reaction product was resuspended in ether, and filtered. The precipate was washed twice in ether, then dissolved in e thanol/water (20:1) by mild heating, avoiding the boiling point. The undissolved residue was removed by filtration at $80^{\circ} \mathrm{C}$ through glass wool, and the solution was allowed to cristallyze on ice. The final product yielded $85 \%$ 6-methoxy- $N$-e thylquinolinium iodide: a bright yellow solid with a fusion point of $184^{\circ} \mathrm{C}$. The properties of MEQ fluorescence were defined on a Stern-Volmer plot $\left(F_{0} / F=1+K_{\mathrm{Cl}}[\mathrm{Cl}]\right.$, in which $F_{0}$ and $F$ are the fluorescence intensities in the absence and presence of chloride, and $[\mathrm{Cl}]$ corresponds to the chloride concentration. The data were obtained by measuring the fluorescence of $\mathrm{KCl}$ solutions (from 0 to $50 \mathrm{mM}$ ) supplemented with $1 \mu \mathrm{M}$ MEQ (excitation, $350 \mathrm{~nm}$; emission, $440 \mathrm{~nm}$; filters were from Chroma (Paris, France)) using a SPEX Fluorolog spectrofluorometer and analyzed with DM3000 software (Jobin Yvon, France). The plot was linear, with a Stern-Volmer constant of $149 \mathrm{M}^{-1}$ (Fig. 1). The plots obtained using the same solutions supplemented with the different NSAIDs (aspirin, indomethacin, ibuprofen) did not modify the Stern-Volmer constant (Fig. 1).

The measurements of intracellular MEQ fluorescence change were carried out as previously described. ${ }^{17}$ Briefly, T-84 cells subcultured on glass slides (control cells, and those treated for $48 \mathrm{~h}$ with NSAIDs) were washed from culture medium, then loaded with MEQ and $\mathrm{I}^{-}$for $10 \mathrm{~min}$ in hypotonic iodine solution ( $1: 2$ dilution of the isotonic solution, $\mathrm{pH} 7.4$, adjusted with $\mathrm{NaOH}$, containing the following reagents: $138 \mathrm{mmol} / \mathrm{l} \mathrm{NaI}, \quad 2.4 \mathrm{mmol} / \mathrm{l} \quad \mathrm{K}_{2} \mathrm{HPO}_{4}, \quad 10 \mathrm{mmol} / \mathrm{l}$ Hepes, $1 \mathrm{mmol} / 1 \mathrm{CaCl}_{2}, 10 \mathrm{mmol} / \mathrm{l}$ glucose) and allowed to recover for $10 \mathrm{~min}$ in isotonic $\mathrm{I}^{-}$solution before being placed in a perfusion chamber on the stage of an inverted microscope (Diaphot, Nikon, France), where they were continuously perfused at $37^{\circ} \mathrm{C}$ with isotonic iodide solution. After a $2 \mathrm{~min}$

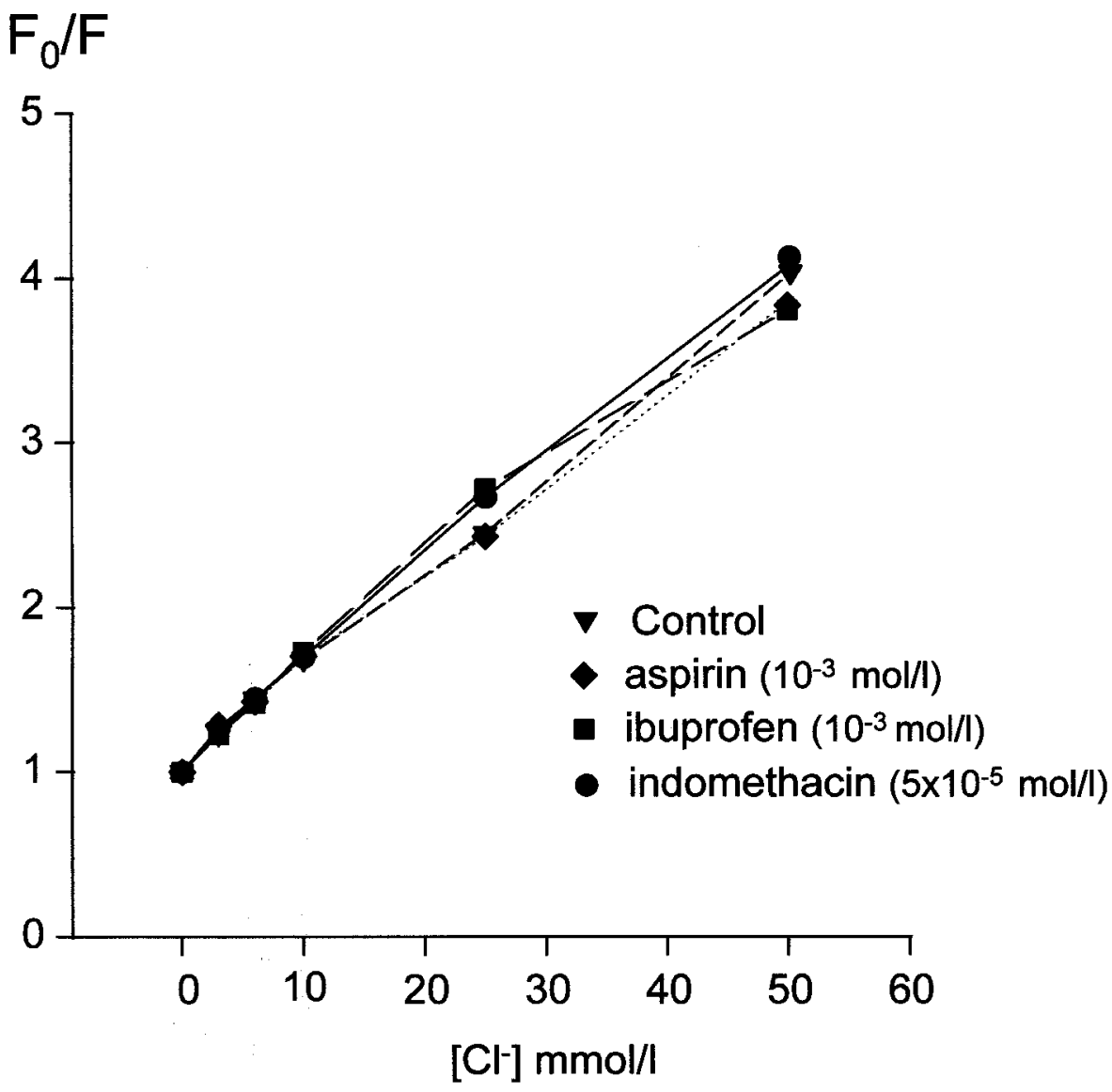

FIG. 1. Stern-Volmer plot. The plot was established by measuring the fluorescence of a $1 \mathrm{mmol} / \mathrm{MEO}$ solution, to which was added increasing amounts of $\mathrm{KCl}$ from 0 up to $50 \mathrm{mmol} / \mathrm{l}$. The determinations were performed in water alone $(\boldsymbol{\nabla})$, then with $10^{-3} \mathrm{~mol} / \mathrm{l}$ aspirin $(\bullet), 10^{-3} \mathrm{~mol} / \mathrm{l}$ ibuprofen $(\square)$, or $5 \times 10^{-5} \mathrm{~mol} / \mathrm{l}$ indomethacin $(\bullet)$. 


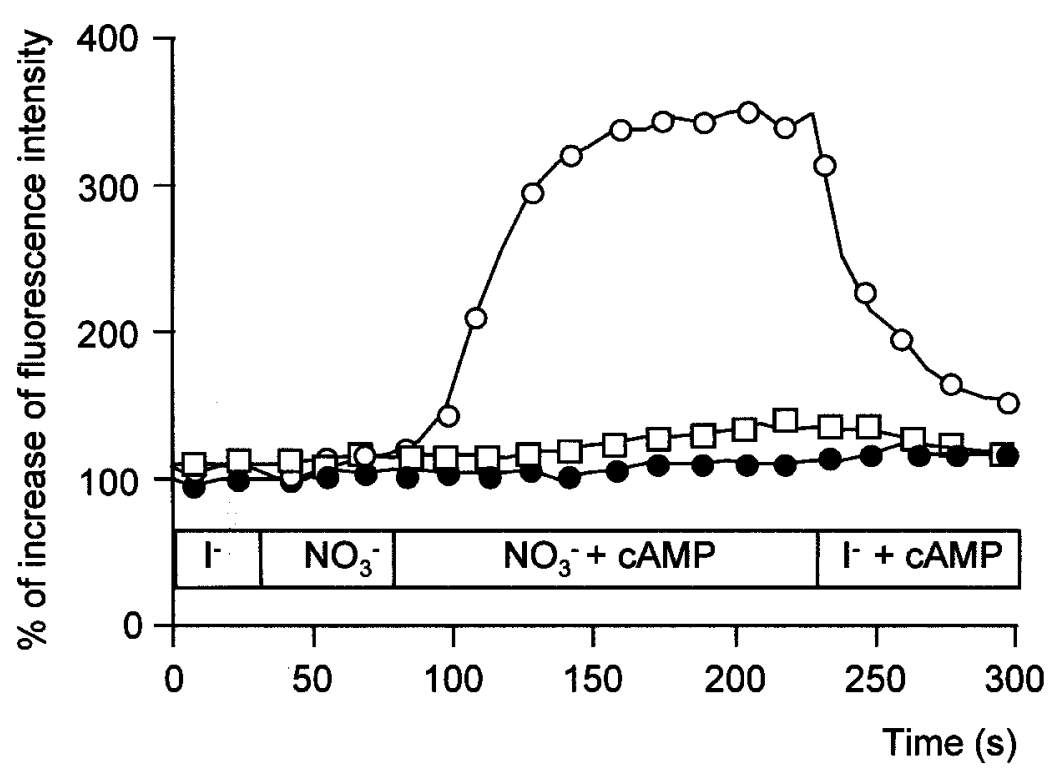

\section{$\square$ untransfected LLCPK cells \\ O CFTR-LLCPK cells \\ - $\triangle F 508-C F T R$ LLCPK cells}

FIG. 2. Validation of the MEQ technology. The fluorescence of intracellular MEQ was registered in untransfected LLCPK cells $(\square)$ and in LLCPK cells expressing either the wild type CFTR $(\bigcirc)$ or the $\Delta \mathrm{F}_{508}$-CFTR $(\bullet)$, under sequential anionic substitutions of the superfusing medium and addition of permeant cpt-cAMP, as indicated in the inset and described in materials and methods.

perfusion period, $\mathrm{I}^{-}$ions were replaced by $\mathrm{NO}_{3}{ }^{-}$ions. Because nitrate does not interact with MEQ, fluorescence increases as cell iodide flows from the cell through anion pathways in the plasma membrane, unmasking possible basal anion conductance. Changes in fluorescence under basal conditions, and with the cAMP cocktail $\left(5 \times 10^{-4} \mathrm{~mol} / 1 \mathrm{l} 8\right.$-(4-chlorophenylthio)-cAMP (cpt-cAMP) and $10^{-4} \mathrm{~mol} / \mathrm{l}$ IBMX) in the nitrate perfusion solution were recorded. The whole experiment was performed w ithout NSAIDs in the perfusion solutions. Fluorescence from the MEQ was measured in single cells with a digital imaging system and a CDD camera (Photonics Science, UK), and the results were analyzed using Imstar software (Paris, France). The initial rate of increase of MEQ fluorescence was measured in basal $\left(\Delta F_{\text {basal }} / \Delta t\right)$ and stimulato ry $\left(\Delta F_{\mathrm{cAMP}} / \Delta t\right)$ conditions. ${ }^{17}$

To validate the MEQ technology as a method for investigating CFTR gene function, we used LLCPK cells stably transfected with the wild-type or the $\triangle$ F508-CFTR-mutate d human cDNA CFTR gene. ${ }^{18}$ The cells were then assayed with the MEQ technology already described. Figure 2 shows that the function of CFTR gene induces an increase in the rate of fluorescence after the addition to the perfusate of the cAMP cocktail in the CFTR-LLCPK cells. No cAMPdependent fluorescence changes were detected in LLCPK nontransfected cells or $\Delta$ F508-CFTR-LLCPK cells. Thus, the MEQ assay can be taken as an index of CFTR activity.

\section{Statistical analysis}

Statistical analysis was by unpaired Student's $t$-test, and, where appropriate, by analys is of variance, with $P<0.05$ considered statistically significant.

\section{Results}

\section{Variation in CFTR mRNA levels}

The modulation of CFTR gene expression by NSAIDs w as investigated by Northern blot analysis, performed on proliferating cells.

The relative amount of CFTR gene products (normalized to $\beta$-actin products) was first determined in cells treated for $24 \mathrm{~h}$ with aspirin, ibuprofen and indomethacin. Figure $3 \mathrm{~A}$ and $\mathrm{B}$ shows that, under our experimental conditions, aspirin $\left(5 \times 10^{-4} \mathrm{~mol} / \mathrm{l}\right)$, ibuprofen $\left(5 \times 10^{-4} \mathrm{~mol} / \mathrm{l}\right)$, and indomethacin $\left(2 \times 10^{-5} \mathrm{~mol} / \mathrm{l}\right)$ reduced the amount of CFTR mRNA in T-84 cells.

After treating the cells for $24 \mathrm{~h}$ with aspirin, the amount of CFTR mRNA was unaltered by low concentrations of the drug, and was decreased by the concentrations larger than $10^{-4} \mathrm{~mol} / \mathrm{l}$ (Fig. 4A). A half- 


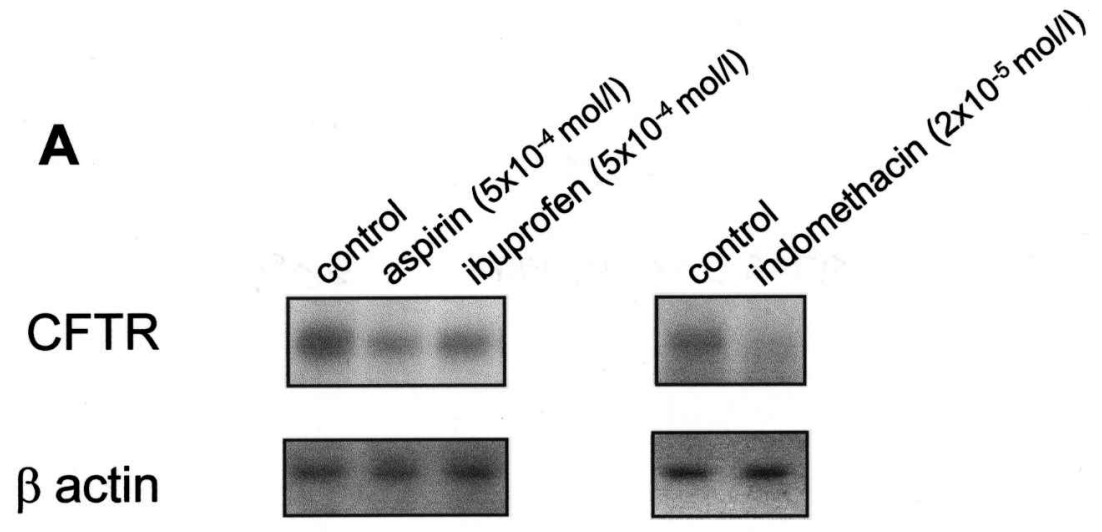

B

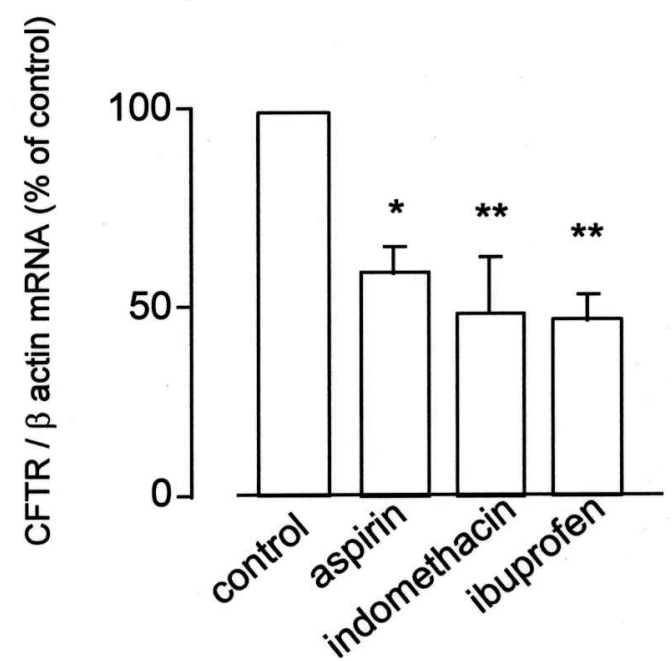

FIG. 3. Effects of aspirin, indomethacin, and ibuprofen on CFTR mRNA content in T-84 cells. (A) Representative Northern blot performed with $15 \mu \mathrm{g}$ total RNA extracted from cells treated for $24 \mathrm{~h}$ with the indicated concentrations (mol/l) of NSAIDs. (B) Amounts of CFTR transcripts normalized to those of $\beta$-actin mRNA. Each value is the mean \pm SE of four experiments. ${ }^{*} P<0.05$; ** $P<0.01$

maximal inhibition was observed with aspirin concentrations close to $10^{-3} \mathrm{~mol} / \mathrm{l}$. $\beta$-actin transcripts were unchanged. Figure $4 \mathrm{~B}$ shows the action of aspirin in relation to time, with the concentration $2 \times 10^{-3} \mathrm{~mol} / \mathrm{l}$ (corresponding to an $80 \%$ inhibition of CFTR transcripts after $24 \mathrm{~h}$ of treatment) chosen for these experiments. After $6 \mathrm{~h}$ of treatment, a $50 \%$ inhibition was observed, and the effect was greatest after $9 \mathrm{~h}$. Together, the data show that the CFTR downregulation is concentration and time dependent. Indomethacin $\left(10^{-5}\right.$ and $\left.2 \times 10^{-5} \mathrm{~mol} / \mathrm{l}\right)$ and ibuprofen $\left(10^{-4}\right.$ and $\left.5 \times 10^{-4} \mathrm{~mol} / \mathrm{l}\right)$ also significantly decreased CFTR mRNA levels in a concentration-dependent manner (Fig. 5). The cell content in $\beta$-actin mRNA was not altered by indomethacin or ibuprofen at any concentration (result not shown).

A relationship between the anti-inflammatory effects of aspirin, indomethacin, and ibuprofen, and their ability to decrease CFTR mRNA might proceed from their capacity to inhibit cyclooxygenase activity. To test this hypothesis, exogenous prostaglandin $\mathrm{E}_{2}$ $\left(\mathrm{PGE}_{2}\right)$ was added to the cells at the same time as the NSAIDs. As show $\mathrm{n}$ in Fig. 6, $10^{-6} \mathrm{~mol} / \mathrm{l}$ exogenous $\mathrm{PGE}_{2}$ by itself decreased cell CFTR mRNA content, and when added with aspirin, indomethacin, and ibuprofen, it did not prevent their down-regulating effect. Therefore, the decrease in CFTR gene expression induced by the NSAIDs cannot be linked to the inhibition of cyclooxygenase activity.

\section{Functional studies: MEQ assay}

To determine whether the NSAIDs modulated the function of CFTR protein, we performed a MEQ assay, in the absence of the drugs, on T-84 cells treated for 24 and $48 \mathrm{~h}$ with $5 \times 10^{-4} \mathrm{~mol} / \mathrm{l}$ aspirin, $5 \times 10^{-4} \mathrm{~mol} / \mathrm{l}$ ibuprofen, and $2 \times 10^{-5} \mathrm{~mol} / \mathrm{l}$ indo methacin (Table 2). The results were compared with 

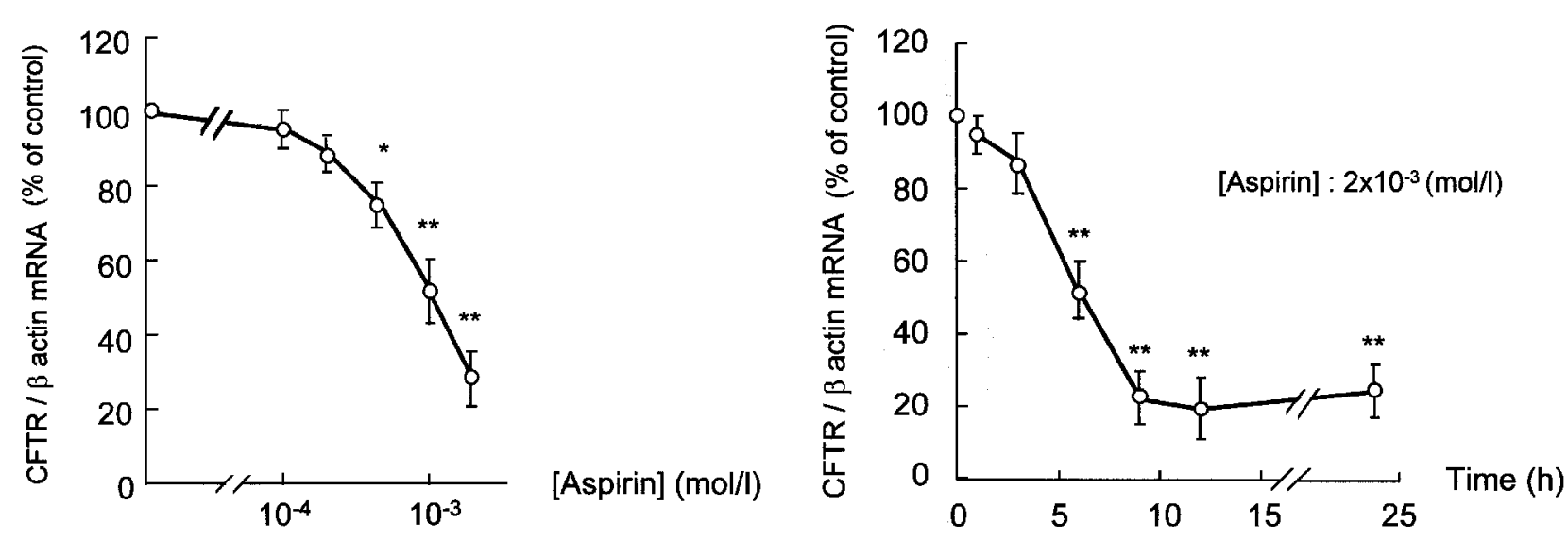

FIG. 4. Northern blot analysis of concentration and time dependence of CFTR mRNA decay induced by aspirin in T-84 cells. The Northern blots were performed using $15 \mu \mathrm{g}$ total mRNA. The cell content in CFTR mRNA are normalized to the content in $\beta$-actin mRNA, and the results are expressed as a percentage of the ratio determined on control cells. (A) Concentration dependence. Cells were treated for $24 \mathrm{~h}$ with $0,10^{-4}, 5 \times 10^{-4}, 10^{-3}$, and $2 \times 10^{-3} \mathrm{~mol} / \mathrm{l}$ aspirin. Each value is the mean $\pm \mathrm{SE}$ of six determinations. ${ }^{*} P<0.05 ;{ }^{*} P<0.01$. (B) Time dependence. Cells were treated with $2 \times 10^{-3} \mathrm{~mol} / \mathrm{l}$ aspirin for $0,1,3,6,9,12$ and $24 \mathrm{~h}$. Each value is the mean \pm SE of five determinations. ${ }^{* *} P<0.01$.

those obtained with untreated cells studied on the same day. In the control (untreated) T-84 cells, addition of the permeant cAMP (cpt-cAMP, $\left.5 \times 10^{-4} \mathrm{~mol} / \mathrm{l}\right)$ to the nitrate-containing solution augmented the rate of increase of MEQ fluorescence, quantified by the ratio $\Delta F_{\text {cAMP }}{ }^{\mathrm{cl}} / \Delta F_{\text {basal }}{ }^{\text {ctl }}$ (mean values, $7.8 ; n=28$; Table 2$)$. This points to activation of the cAMP-regulated anion pathway(s) (Fig. 7). The 24-h treatment of T-84 cells with either drug did not change the cpt-cAMP-induced increase in the rate of MEQ fluorescence observed in $\mathrm{NO}_{3}{ }^{-}$-containing solutions (data not shown). On the other hand, the cptcAMP-induced increase in the rate of MEQ fluorescence observed in $\mathrm{NO}_{3}{ }^{-}$-containing solutions was altered in cells treated during $48 \mathrm{~h}$ with the NSAIDs. It was abolished in the cells treated with aspirin $\left(10^{-3} \mathrm{~mol} / \mathrm{l}\right)$, (Fig. $7 \mathrm{~A}$ and Table 2, row 'aspirin', comparing columns 2 and 5 , or columns 3 and 6 ) and decreased in the cells treated for $48 \mathrm{~h}$ with $5 \times 10^{-4} \mathrm{~mol} / 1$ ibuprofen (Fig. $7 \mathrm{~B}$ and Table 2, row 'ibuprofen', comparing columns 2 and 5, or 3 and 6 ) or $2 \times 10^{-5} \mathrm{~mol} / \mathrm{l}$ indomethacin (Table 2 , row 'indo $\mathrm{m}$ ethacin', comparing column 2 and 5, or 3 and 6).

Using the MEQ methodology, we have thus show $n$ a decrease in cAMP-induced anionic flux provoked by the treatment of the cells with aspirin, indomethacin, and ibuprofen, and also demonstrated a particular action of ibuprofen and aspirin on T-84 cell basal anion conductance. Under our experimental protocol, this basal anion conductance (evidenced by the light emission provoked by replacing $\mathrm{I}^{-}$by $\mathrm{NO}_{3}^{-}$in the superfusing solution) was small (as Fig. 7A and Table

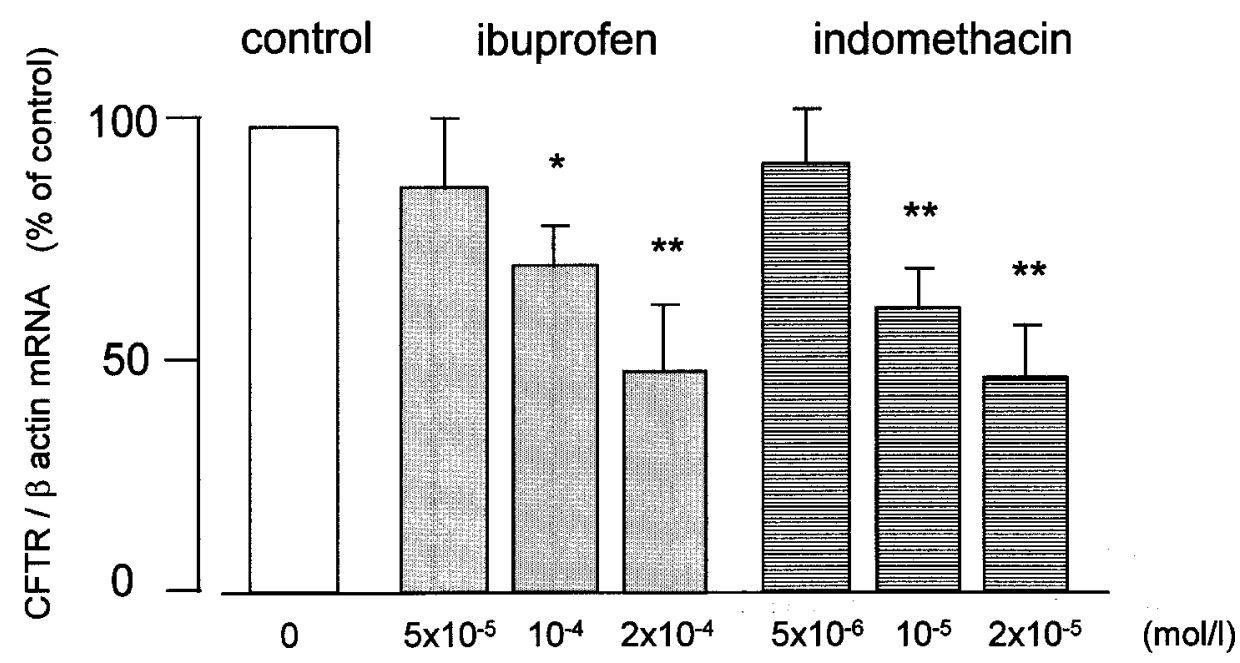

FIG. 5. Concentration dependence of the decay of CFTR transcripts induced by ibuprofen and indomethacin. Northern blots were performed using $15 \mu \mathrm{g}$ total RNA extracted from cells treated for $24 \mathrm{~h}$ with various concentrations of ibuprofen and indomethacin. The cell content in CFTR mRNA is normalized to the content in $\beta$-actin mRNA, and the results are expressed as a percentage of the ratio determined on control cells. ${ }^{*} P<0.05 ;{ }^{*} P<0.01(n=5)$. 


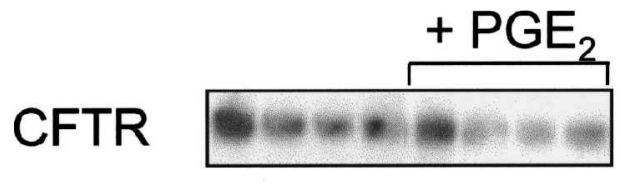

$\beta$ actin

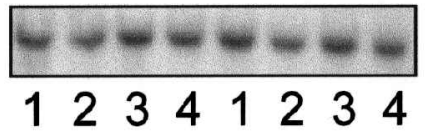

\section{1 : control}

$2:+$ aspirin $\left(10^{-3} \mathrm{~mol} / \mathrm{l}\right)$

$3:+$ ibuprofen $\left(5 \times 10^{-4} \mathrm{~mol} / \mathrm{l}\right)$

$4:+$ indomethacin $\left(2 \times 10^{-5} \mathrm{~mol} / \mathrm{l}\right)$

\section{$\left[\mathrm{PGE}_{2}\right]: 10^{-6} \mathrm{~mol} / \mathrm{l}$}

FIG. 6. Absence of the effect of exogenous $\mathrm{PGE}_{2}$. Typical Northern blot performed using $15 \mu \mathrm{g}$ total RNA extracted from cells treated for $24 \mathrm{~h}$ with aspirin, ibuprofen, and indomethacin in the absence and the presence of exogenous $\mathrm{PGE}_{2}\left(10^{-6} \mathrm{~mol} / \mathrm{l}\right)$
2, row 'aspirin', column 1). Tre atment of the cells with the three tested NSAIDs modulated this parameter in various ways (column 4, Table 2). Aspirin decreased it tw ofold (columns 4 and 7, Table 2), indomethacin was without effect (Table 2, row 'indomethacin', columns 4 and 7), and ibuprofen increased it tw ofold (Figure $7 \mathrm{~B}$ and Table 2, row 'ibuprofen', columns 4 and 7).

\section{Discussion}

The present study shows that aspirin, indomethacin, and ibuprofen, three nonsteroidal anti-inflammatory drugs widely used in clinical medicine, decrease both the amount of CFTR transcripts and the function of CFTR protein in human T-84 cells.

The decrease in CFTR mRNA does not appear to be toxic, because there was no sign of death in cells incubated for $48 \mathrm{~h}$ with the highest concentrations of the drugs used, and because the amount of $\beta$-actin mRNA did not change in parallel with that of CFTR mRNA. The high concentrations of aspirin and other drugs required to down-regulate CFTR gene expression raise two issues: first, the possible existence of such an effect during anti-inflammatory treatment;

(A)

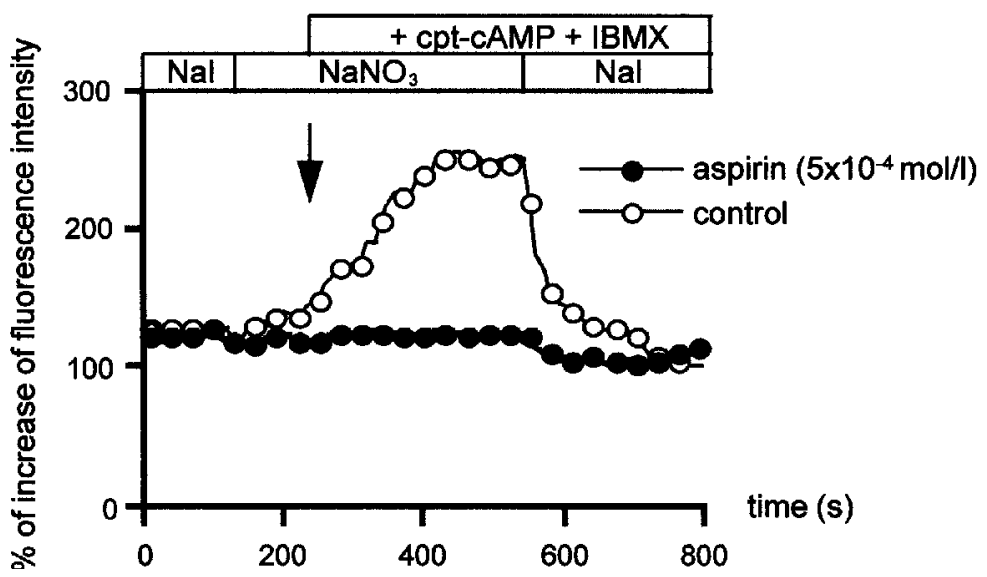

(B)

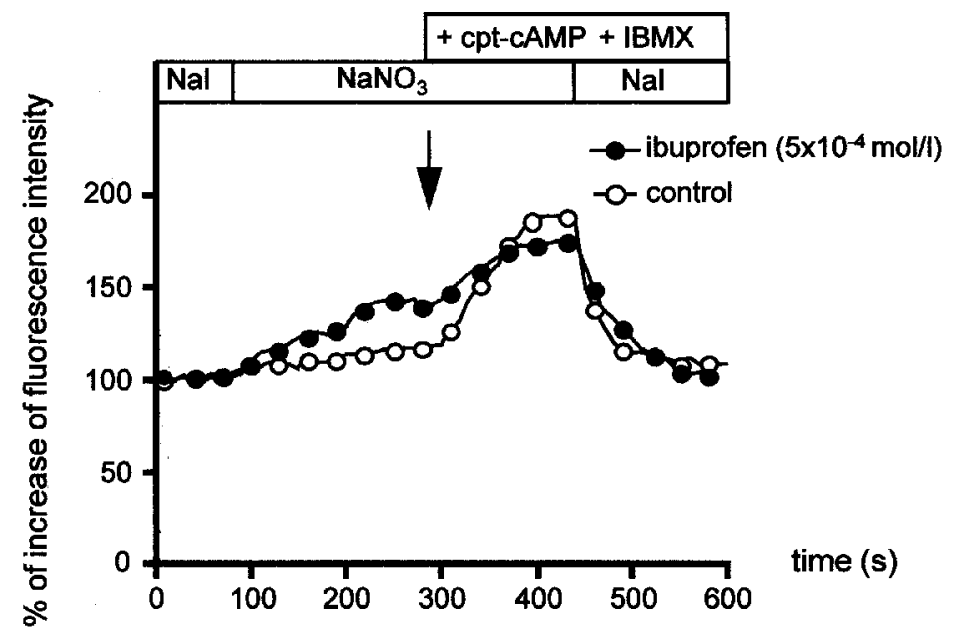

FIG. 7. The fluorescence of intracellular MEQ was measured with respect to time under control conditions and after $48 \mathrm{~h}$ of treatment with either $5 \times 10^{-4} \mathrm{~mol} / /$ aspirin (A) or $5 \times 10^{-4} \mathrm{~mol} / \mathrm{l}$ ibuprofen (B). The sequence of buffer substitutions is indicated in the inset. 
Table 2. Analysis of MEQ fluorescence in T84 cells

\begin{tabular}{|c|c|c|c|c|c|c|c|}
\hline & $\begin{array}{c}\Delta F_{\text {basal }}{ }^{c t /} / \Delta t \\
\text { untreated cells } \\
\text { (column 1) }\end{array}$ & $\begin{array}{c}\Delta F_{\mathrm{cAMP}}{ }^{\mathrm{ctl} /} / \Delta t \\
\text { untreated cells } \\
\text { (column 2) }\end{array}$ & $\begin{array}{c}\Delta F_{\text {cAMP }}{ }^{\mathrm{ctl} /} / \Delta F_{\text {basal }}{ }^{\mathrm{ctl}}, \\
\text { untreated cells } \\
\text { (column } 3 \text { ) }\end{array}$ & $\begin{array}{c}\Delta F_{\text {basal }} \text { test }^{\text {t }} / \Delta t \\
\text { treated cells } \\
\text { (column } 4 \text { ) }\end{array}$ & $\begin{array}{c}\Delta F_{\text {cAMP }}{ }^{\text {test }} / \Delta t, \\
\text { treated cells } \\
\text { (column 5) }\end{array}$ & $\begin{array}{c}\Delta F_{\text {cAmP }}{ }^{\text {test }} / \Delta F_{\text {basal }}{ }^{\text {test }} \\
\text { treated cells } \\
\text { (column } 6 \text { ) }\end{array}$ & $\begin{array}{c}\Delta F_{\text {basal }}{ }^{\text {test }} / \Delta F_{\text {basal }}{ }^{\mathrm{ctl}} \\
(\text { column } 7)\end{array}$ \\
\hline $\begin{array}{l}\text { Aspirin } \\
(0.5 \mathrm{mmol} / /)\end{array}$ & $\begin{array}{c}0.26 \pm 0.04 \\
(10)\end{array}$ & $\begin{array}{c}2.02 \pm 0.38 \\
(10)\end{array}$ & 7.8 & $\begin{array}{c}0.10 \pm 0.06^{a} \\
(10)\end{array}$ & $\begin{array}{c}0.19 \pm 0.03 \\
(10)\end{array}$ & 1.9 & 0.38 \\
\hline $\begin{array}{l}\text { Ibuprofen } \\
(0.5 \mathrm{mmol} / \mathrm{l})\end{array}$ & $\begin{array}{c}0.24 \pm 0.04 \\
(6)\end{array}$ & $\begin{array}{c}2.15 \pm 0.14 \\
(6)\end{array}$ & 8.9 & $\begin{array}{c}0.58 \pm 0.05^{\mathrm{b}} \\
(6)\end{array}$ & $\begin{array}{c}1.40 \pm 0.15 \\
(6)\end{array}$ & 2.4 & 2.41 \\
\hline $\begin{array}{l}\text { Indomethacin } \\
(2 \mu \mathrm{mol} / \mathrm{l})\end{array}$ & $\begin{array}{c}0.29 \pm 0.02 \\
(8)\end{array}$ & $\begin{array}{c}1.80 \pm 0.18 \\
(8)\end{array}$ & 6.9 & $\begin{array}{c}0.25 \pm 0.04^{c} \\
(8)\end{array}$ & $\begin{array}{c}0.58 \pm 0.07 \\
(8)\end{array}$ & 2.3 & 0.86 \\
\hline
\end{tabular}

Untreated cells: $\Delta F_{\text {basal }}{ }^{\mathrm{ctl} /} / \Delta t$, changes in MEQ fluorescence observed in unstimulated cells; $\Delta F_{\mathrm{cAMP}}{ }^{\mathrm{ctl} /} / \Delta F_{\mathrm{basal}}{ }_{\mathrm{ctl}}$, changes in MEO fluorescence observed in cells exposed to cAMP cocktail; $\Delta F_{\mathrm{cAMP}}{ }^{\mathrm{ct} /} / \Delta F_{\text {basal }}{ }^{\mathrm{ctl}}$, values obtained by dividing values from column 2 by those from column 1 . NSAIDS-treated cells for $48 \mathrm{~h}: \Delta F_{\text {basal }}$ test $/ \Delta t$, changes observed in unstimulated cells; $\Delta F_{\mathrm{cAMP}} \mathrm{test}^{\text {tes }} \Delta t$, changes in MEQ fluorescence observed in cells exposed to cAMP cocktail; $\Delta F_{\text {cAMP }}{ }^{\text {test }} / \Delta F_{\text {basal }}{ }_{\text {test }}$, values obtained by dividing values from column 5 by those from column $4 ; \Delta F_{\text {basal }}{ }^{\text {test }} / \Delta F_{\text {basal }}{ }^{\text {ctl }}$, values obtained by dividing the values from column 4 by those from column 1 . Numbers in parentheses corresponds to the number of independent experiments.

a Statistically different from values presented in the line aspirin, column 1, at $P<0.05$.

bStatistically different from values presented in the line ibuprofen, column 1 , at $P<0.01$.

${ }^{\mathrm{c}}$ Not significant from the values presented in the line indomethacin, column 1.

second, the relationship between the modulation of CFTR gene expression and cyclooxygenase inhibition. Plasma concentrations of aspirin as high as those required to modulate CFTR gene expression in our experimental model (over $10^{-4} \mathrm{~mol} / \mathrm{l}$ ) have been reported when the drug is used for sustained periods, ${ }^{19}$ so our results may have clinical relevance. However, the concentrations of aspirin, indo methacin, or ibuprofen required to reduce CFTR gene ex pression in T-84 cells are not consistent with the direct implication of cyclooxygenase (COX) inhibition, whether of the constitutive COX-1 or the inducible COX-2. Aspirin, indomethacin, and ibuprofen are better inhibitors of COX-1 than of COX-2, and thus have a higher $\mathrm{ID}_{50}$ for COX-2 than for COX-1; but even their reported $\mathrm{ID}_{50}$ for $\mathrm{COX}-2^{20}$ is at least 10 -fold lower than their active concentrations in the present study. Furthermore, the failure of ex ogenous $\mathrm{PGE}_{2}$ to prevent the decrease in CFTR gene expression caused by aspirin, indome thacin, and ibuprofen suggests that this effect of the NSAIDs does not involve the inhibition of prostaglandin synthesis. The NSAID concentrations used in the present study are comparable with those used in recent studies of the effects of these drugs on the nucleus. This is the case for indomethacin binding to the peroxysome prolife rator-activated receptor $\gamma$ $(\operatorname{PPAR} \gamma){ }^{21}$ High concentrations of aspirin are also required to modulate the effect of the transcription factors such as NFKB, AP1, or $\mathrm{HSF}^{7-9}$ which possess specific binding sites in the CFTR promoter, ${ }^{12}$ and may thus be involved in the NSAID-induced down-regulation of CFTR gene expression. Further studies will be required to demonstrate the existence of any such regulation of CFTR gene expression by aspirin and its derivatives. Since the transcription factors affected by aspirin are activate during inflammation, this putative mechanis $m$ of negative modulation of CFTR expression would also result from an anti-inflammatory effect of the NSAIDs.
The cAMP-stimulated anionic efflux measured by the MEQ assay was also decreased by treating the T-84 cells with aspirin, indomethacin, or ibuprofen. Since the ex periments were performed without NSAIDs, this effect of the NSAIDs differed from the immediate inhibition of the ionic transport described in other studies. $^{2-6}$ The present data demonstrate that the NSAIDs also exert a delayed action on anionic fluxes. The results showing differences in the concentration dependence of cAMP-regulated anion fluxes and in the modulation of CFTR mRNA production argue agains $t$ a direct causal relationship between the two effects of NSAIDs. Two points may be made. First, the relative inhibition of cAMP-triggered anion efflux is larger than the relative decrease in CFTR transcripts. This was particularly obvious in cells tre ated with $5 \times 10^{-4} \mathrm{~mol} / \mathrm{l}$ aspirin, which no longer responded to cAMP in term of anionic efflux, despite a decrease of only about $30 \%$ in their CFTR mRNA content. Second, very few CFTR channels seem to be necessary for this function. ${ }^{11}$ In normal tissues, this small number of channels is correlated with a quantity of CFTR gene products too small to be visualized by Northern blotting. Our results therefore suggest that aspirin, ibuprofen and indomethacin have long-acting effects on CFTR function, in addition to their action on CFTR gene expression. The NSAIDs may alter the cytoplasmic processing and/or turn-over of the CFTR protein, or change its potential for activation. These processes are modulated by variations in temperature and by various compounds (butyrate, glycerol) (a review ${ }^{22}$ ), and the demonstration of the ir sensitivity to NSAIDs would be partic ularly interesting in the cystic fibrosis context. Immunoblots of CFTR protein in control cells and cells ex posed for $48 \mathrm{~h}$ to $0.5 \mathrm{mmol} / \mathrm{l}$ aspirin, incubated with radiolabeled methionine then incubated for 2-30 h showed no clear alteration in the time-course of the CFTR protein glycosylation or degradation, but only a general decrease in the intensities of immature and 
fully glycosylated CFTR protein bands. The latte $\mathrm{r}$ were very faint in NSAID-treated cells (result not shown). These results suggest that the re is an aspirin-induced decrease in the synthesis of native CFTR protein, but further studies are required to specify the action of aspirin on CFTR protein processing.

A decrease in endogenous CFTR activators caused by NSAIDs cannot be due to altered production of intracellular endogenous cAMP because the MEQ assay was performed with exogenous permeant cptcAMP. Other cytoplasmic factors that control CFTR function may also be affected by the NSAIDs. For example, indomethacin acts as an irreversible inhibitor of cAMP-dependent protein kinase in rabbit ileal mucosa, ${ }^{23}$ and inhibits phospholipase A2 in rabbit polymorphonuclear leukocytes. ${ }^{24}$ Such effects could alter CFTR function directly or indirectly, but are unlikely since there were no changes in cAMPinduced MEQ fluorescence in cells incubated for only $24 \mathrm{~h}$ with NSAIDs.

However, the use of the MEQ methodology did reveal that ibuprofen also appears to induce a new cAMP-independent anion conductance, which can be activate $\mathrm{d}$ in T-84 cells without furthe $\mathrm{r}$ stimulation. This effect may correspond to an increased number and/or function of another chloride channel, and thus contribute to the improved clinical status of $\mathrm{CF}$ patients treated with ibuprofen.

The present results emphasize the possible diversity of the NSAID effects, since these drugs, which inhibit CFTR activity accutely, ${ }^{2-6}$ also appear to produce a delayed decrease in CFTR gene expression and cAMP-stimulated anionic efflux. The delayed decrease in CFTR protein function does not appear to result from a decrease in gene expression alone. The NSAIDs thus appear to have a broad spectrum of action on CFTR, which may reflect a gene ral modific ation of cell metabolism. This suggest that CFTR acts as a 'housekeeping gene' that can adapt to various physiological or pharmacological disturbances. ${ }^{25}$

ACKNOWLEDGEMENTS: This work was supported by grants from Institut National de la Santé et de la Recherche Médicale, Centre National de la Recherche Scientifique and Association Française de Lutte contre la Mucoviscidose (AFLM). The english text was edited by G. Watts.

\section{References}

1. Vane J. Inhibition of prostaglandin synthesis as a mechanism of action for aspirintike drugs. Nature-New Biol 1971; 231: 232-235.

2. Devor DC, Schultz BD. Ibuprofen inhibits cystic fibrosis trans me mbrane conductance regulator-mediated $\mathrm{Cl}-$ secretion. J Clin Invest $1998 ; 102$. 679-687.
3. Gogelein H, Dahlem D, Englert HC, Lang HJ. Flufenamic acid, mefenamic acid and niflumic acid inhibit single nonselective cation channels in the rat exocrine pancreas. FEBS Lett 1990; 268: 79-82.

4. Mochikusi H, Morikaw a A, Tokuyama K, Kuroume T, Chao AC. The effect of non-steroidal anti-inflammatory drugs on the electrical properies of cultured dog tracheal epithelial cells. Eur J Pharmacol 1994; 252: $183-188$.

5. Bialek S, Quong JN, Yu K, Miller SS. Nonsteroidal anti-inflammatory drugs alter chloride and fluid transport in bovine retinal pigment epithelium. Am J Physiol 1996; 270: C1175-C1 189.

6. Busch AE, Herzer T, Wagner CA, Schmidt F, Raber G, Waldegger S, Lang F Positive regulation by chloride channel blockers of Is K channels expressed in Xenopus oocytes. Mol Pharmacol 1994; 46: 750-753.

7. Kopp E, Ghosh S. Inhibition of NF-KB by sodium salicylate and aspirin. Science 1994; 265: 956-959.

8. Dong Z, Huang C, Brown RE, Ma WY. Inhibition of Activator Prote in I activity and neoplastic transformation by aspirin. J Biol Chem 1997; 272: 9962-9970.

9. Jurivich DA, Pachetti C, Oui L, Welk JF. Salicylate triggers heat shock Factor differently than heat. J Biol Chem 1995; 270: 24489-24495.

10. Konstan MW, Byard PJ, Hoppel CL, Davis PB. Effect of high-dose ibuprofen in patients with cystic fibrosis. New Engl J Med 1995; 332: $848-854$.

11. Fulle r CM, Benos DJ. CFTR! Am J Physiol 1992; 263: C267-C286.

12. McDonald RA, Matthews RP, Idzerda RL, McKnight GS. Basal expression of the cystic fibrosis transmembrane conductance regulator gene is dependent on prote in kinase A activity. Proc Natl Acad Sci USA 1995; 92. 7560-7564.

13. Wu KK, Sanduja R, Tsai AL, Ferhanoglu B, Loose-Mitchell DS. Aspirin inhibits interleukin 1-induced prostaglandin $\mathrm{H}$ synthase expression in cultured endothelial cells. Proc Natl Acad Sci 1991; 88: 2384-2387.

14. Low ry DH, Rosebrough WJ, Farr AL, Randall RJ. Prote in measurement with the Folin phenol reagent. J Biol Chem 1995; 193: 265-275.

15. Chomczynski P, Sacchi N. Single step method of RNA isolation by acid guanidium thiocyanate-phenol-chloroform extraction. Anal Biochem 1987; 162: 156-159.

16. Biwersi JB, Verkman AS. Cell permeable fluorescent indicator for cytosolic chloride. Biochem istry 1991; 30: 7879-7883.

17. Fanen P, Labarthe R, Garnier F, Benharouga M, Goossens M, Edelman A. Cystic Fibrosis phenotype associated with pancreatic insufficiency does not always reflect the cAMP-dependent chloride conductive pathway defect. J Biol Chem 1997; 272: 30563-30566.

18. Costa de Beauregard MA, Cherif S, Robine S, Monneret C, Buchwald M, Louvard D. Analyse des mécanismes de rétention du CFTR $\left(\Delta \mathrm{F}_{508}\right)$ dans le réticulum endoplasmique, à l'aide de lignées de cellules rénales épithéliales (LLCPK1) exprimant la protéine CFTR normale ou mutée $\left(\Delta \mathrm{F}_{508}\right)$ prteuse d'un épitope viral antigénique. Néphrologie 1997; 18: 146.

19. Cerletti C, Bonati M, del Maschio A, Galetti F, Dejana E, Tognoni G, de Gae tano G. Plasma levels of salicylate and aspirin in healthy volunteers: relevance to drug interaction on platelet function. J Lab Clin Med 1984; 103: 869-877.

20. Michell JA, Akasereenont P, Thiemermann C, Flower RJ, Vane JR. Selectivity of nonsteroidial antiinflammatory drugs as inhibitors of constitutive and inducible cyclooxygenase. Proc Natl Acad Sci USA 1994; 90: 11693-11697.

21. Jiang C, Ting AT, Seed B. PPAR- $\gamma$ agonis ts inhibit production of monocyte inflammatory cytokines. Nature 1998; 391: 82-86.

22. Kopito RR. Biosynthesis and degradation of CFTR. Physiol Rev 1999; 79: S167-S173.

23. Kantor HS, Hampton M. Indomethacin in submicromolar concentration inhibits cyclic AMP-dependent protein kinase. Nature 1978; 276: $841-842$.

24. Kaplan L, Weiss J, Elsbach P. Low concentrations of indomethacin inhibit phospholipase A2 of rabbit polymorphonuclear leukocytes. Proc Natl Acad Sci USA 1978; 75: 2955-2958.

25. Yoshimura K, Nakamura H, Trapnell BC, Dale mans W, Pavirani A, Lecocq JP, Crystal RG. The cystic fibrosis gene has a 'housekeeping'type promoter and is expressed at low levels in cells of epithelial origin. J Bio Chem 1991; 266: 9140-9144.

\section{Received 30 May 1999;} accepted 24 August 1999 


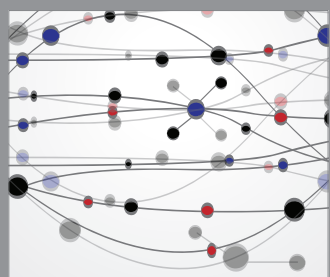

The Scientific World Journal
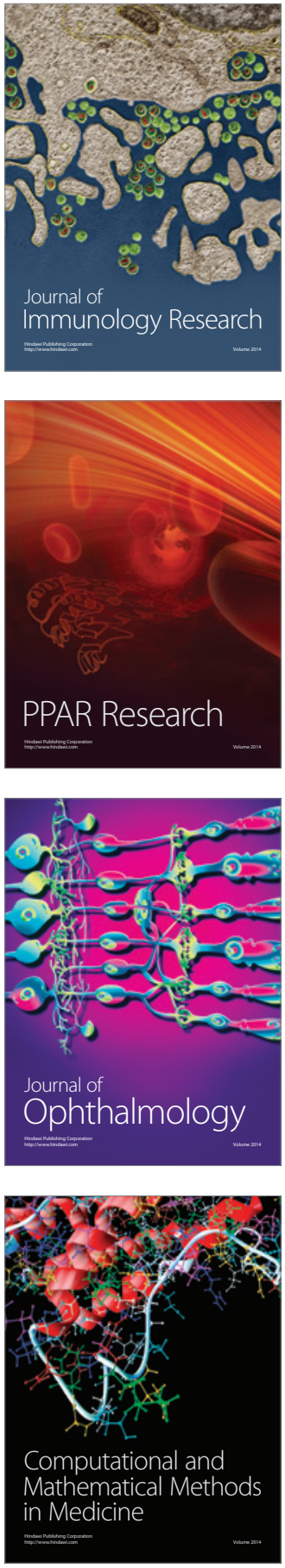

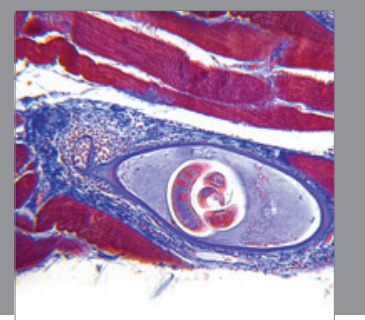

Gastroenterology

Research and Practice
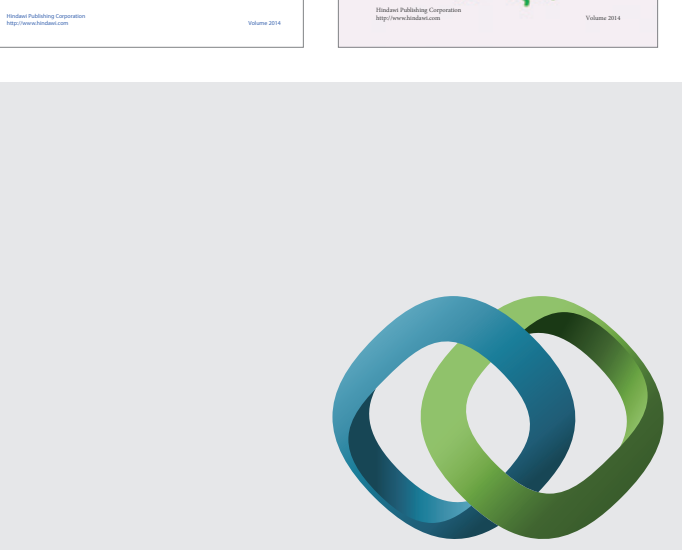

\section{Hindawi}

Submit your manuscripts at

http://www.hindawi.com
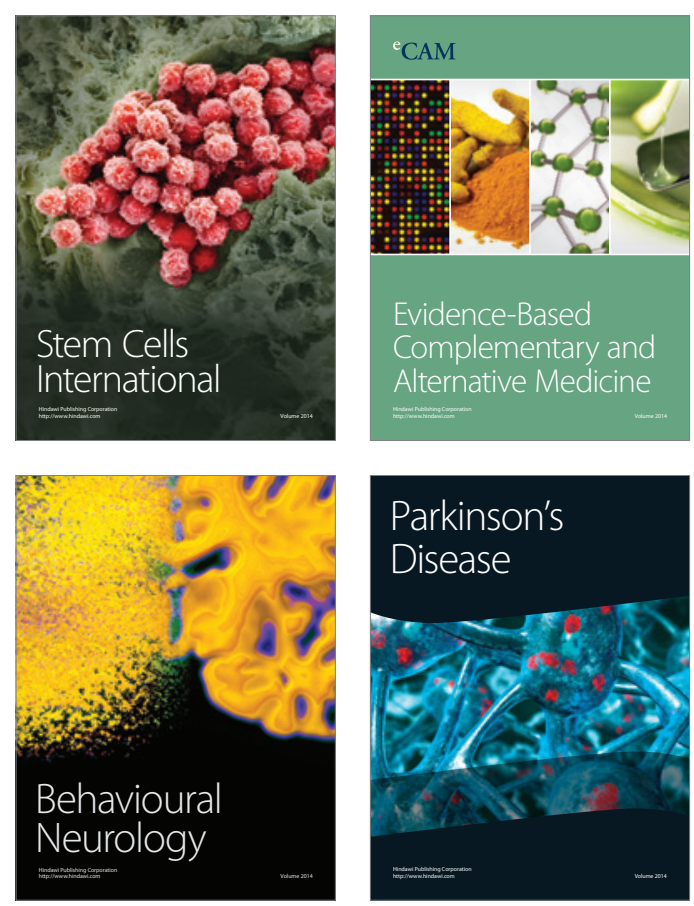

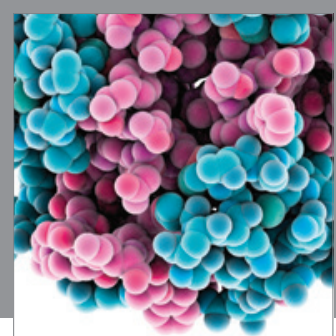

Journal of
Diabetes Research

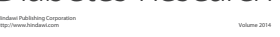

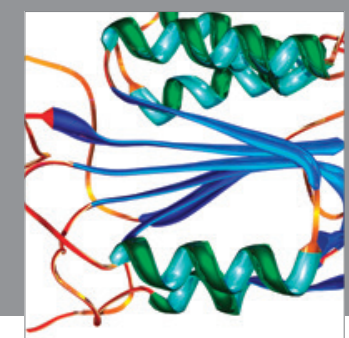

Disease Markers
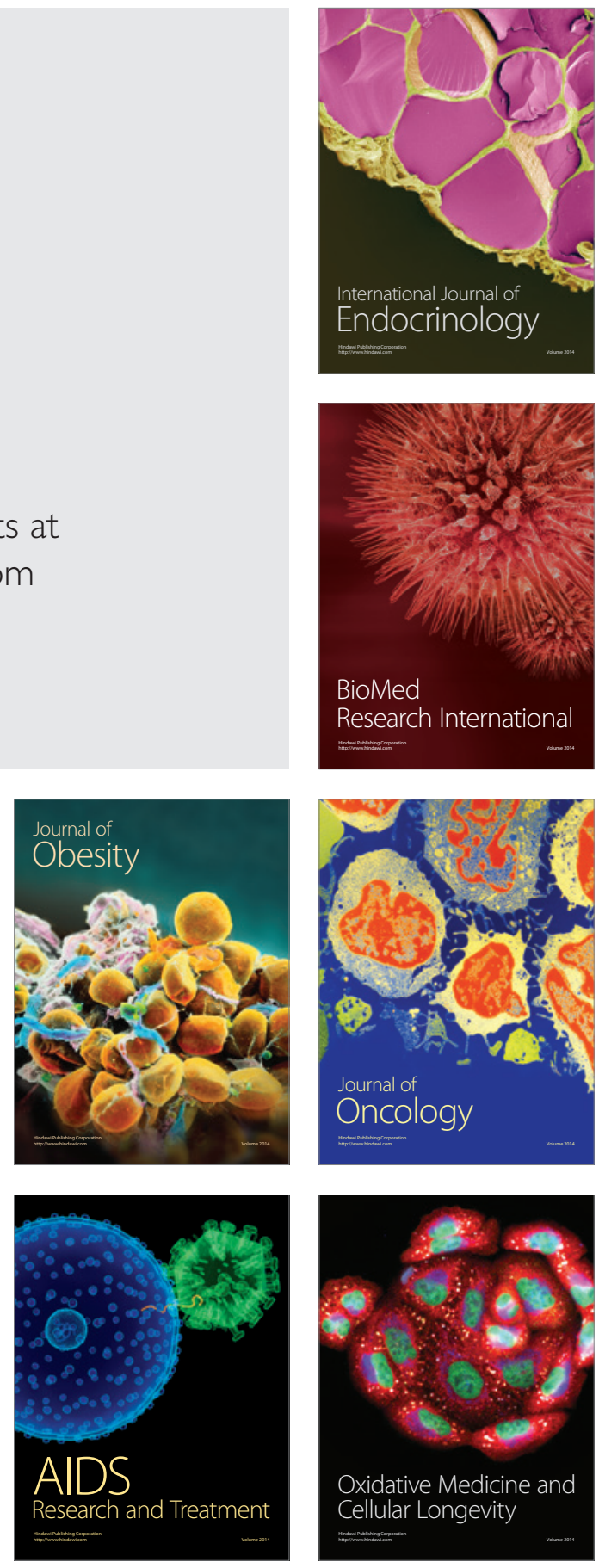